\title{
PENINGKATAN PRODUKTIVITAS TANAMAN PADI SAWAH IRIGASI TERINTEGRASI POPULASI ITIK
}

\author{
Sumini, Holidi dan Widiyanto \\ Program Studi Agroteknologi Fakultas Pertanian Universitas Musi Rawas \\ Sumini.fpunmura@gmail.com
}

\begin{abstract}
ABSTRAK
Penelitian ini bertujuan untuk mengetahui peningkatan produktivitas tanaman padi sawah irigasi dengan integrasi populasi itik. Penelitian dilaksanakan di Kelurahan Ekamarga Kecamatan Lubuk Linggau Selatan II Kota Lubuk Linggau dari Desember 2016 sampai Maret 2017. Metode penelitian yang digunakan adalah Rancangaan Acak Kelompok (RAK). Setiap perlakuan populasi itik (P) diulang 4 kali yang terdiri dari : P0 = Tanpa Itik, P1 $=300$ ekor/ha setara 1 ekor/petak, P2 = 600 ekor/ha setara 2ekor/petak, P3 = 900 ekor/ha setara 3 ekor/ petak, P4 1200 ekor/ha setara 4 ekor/petak, dan P5 = 1500 ekor/ha setara 5 ekor/petak. Hasil penelitian menunjukkan bahwa populasi itik berpengaruh nyata terhadap bobot bulir per malai, berpengaruh sangat nyata terhadap bobot 1000 bulir dan produksi per petak namun tidak berpengaruh nyata terhadap tinggi tanaman, jumlah anakan, dan jumlah anakan produktif. Populasi 2 ekor itik per petak (P2) atau setara dengan 600 ekor per hektar menghasilkan pertumbuhan dan produksi tertinggi.
\end{abstract}

Kata Kunci : Integrasi, Populasi Itik dan Padi

\section{PENDAHULUAN}

Padi merupakan sumber pangan utama yang dapat menjadi penyangga ketahanan pangan nasional. Produksi padi tahun 2015 mencapai 75,55 juta ton gabah kering giling dan mengalami kenaikan sebanyak 4,70 juta ton (6,64\%) bila dibandingkan tahun 2014 . Peningkatan produksi terjadi karena penambahan luas panen seluas 0,51 juta hektar (3,71\%) dan kenaikan produktivitas sebesar 1,45 kuintal/hektar (2,82\%) (Kementerian Pertanian, 2015). Upaya peningkatan produksi padi dengan cara pertanian modern yaitu berupa pertanian terpadu. Pertanian terpadu yang melibatkan tanaman dan ternak menjadi sumber pangan yang beranekaragam sehingga dapat meningkatkan kesejahteraan masyarakat. Penggunaan bahan-bahan kimia baik pupuk maupun pestisida yang tinggi menimbulkan ancaman pencemaran dan kerusakan lingkungan hidup. Untuk mengatasi hal tersebut maka dikembangkan konsep pertanian yang berkelanjutan.

Handaka et a.l (2009), mengemukakan bahwa sistem pertanian terpadu adalah suatu sistem pertanian yang dicirikan adanya keterkaitan yang erat antara komponen tanaman dan ternak dalam suatu kegiatan usaha tani. Penerapan pertanian terpadu (padi 
terintegrasi itik) mampu menekan biaya usaha tani lebih rendah. Keterkaitan ini merupakan faktor penentu keberlanjutan suatu sistem usaha tani. Integrasi antara padi sawah dengan ternak itik mempunyai fungsi sebagai pestisidator, herbisidator, dan mengurangi biaya produksi.

Integrasi antara padi dengan itik mempunyai hubungan yang menguntungkan. Keuntungan dari integritas ini bagi itik adalah tersedianya pakan seperti serangga, rumput, katak, siput, keong, lembing dan biota lain yang ditemuin disawah. Keuntungan yang diperoleh dengan adanya itik di sawah antara lain membantu pemupukan dari kotoran yang dihasilkan, dan terjadi penggemburan tanah karena aktivitas dalam mencari makan, meminimalkan penyiangan gulma yang ada disawah, dan diharapkan dapat mengurangi penggunaan pestisida karna hama dimakan itik sehingga biaya produksi petani juga berkurang (Holidi et al., 2015).

Menurut Beigi et al.(2013), populasi itik yang dapat dilakukan pada lahan sawah mencapai 400-1200 ekor per hektar. Dengan sistem pertanian padi - itik dapat meningkatkan produksi padi mencapai $20 \%$ di bandingkan budidaya padi tanpa itik. Sehingga jumlah populasi itik yang dilepaskan pada lahan sawah menjadi faktor utama dalam pertanian padi-itik (Holidi et al, 2015). Di Indonesia penelitian tentang pertanian terpadu (padi-itik) masih terbatas sehingga perlu dikaji lebih dalam. Berdasarkan uraian diatas dilakukan penelitian tentang peningkatan produktivitas tanaman padi sawah irigasi terintegrasi populasi itik.

\section{METODE PENELITIAN}

Penelitian dilaksanakan di lahan sawah irigasi di Kelurahan Ekamarga Kecamatan Lubuk Linggau Selatan II Kota Lubuk Linggau dengan waktu penelitian dari bulan Desember 2016 sampai Maret 2017. Penelitian menggunakan metode Rancangan Acak Kelompok (RAK) dengan 4 kali ulangan.

$\mathrm{P} 0=$ tanpa itik (kontrol)

$\mathrm{P} 1=300$ ekor/ha setara dengan 1 ekor/petak P2 = 600 ekor/ha setara dengan 2 ekor/petak P3 $=900$ ekor/ha setara dengan 3 ekor/petak P4 = 1200 ekor/ha setara dengan 4 ekor/petak P5 = 1500 ekor/ha setara dengan 5 ekor/petak

Lahan dipupuk organik 10 ton/ha setara dengan $35 \mathrm{~kg} /$ petak setelah itu lahan dibagi 4 ulangan dengan luas petakan $5 \times 7$ meter dengan jarak antara petak $50 \mathrm{~cm}$ dan jarak antar ulangan 1 meter. Penanaman dilakukan pada bibit berumur 10 hst dengan jarak 25 $\times 25 \mathrm{~cm}$. Itik diintegrasikan saat tanaman berumur 10 hst pada setiap petakan. Itik yang digunakan berumur 15 hari, untuk hari pertama sampai hari ketiga itik dilepas selama 3 jam, pada hari ke empat sampai saat tanaman padi berbunga itik dilepas dari pukul 7.00 sampai 17.00. Itik dikandangkan atau ditarik dari sawah saat padi berbunga untuk menghindari gangguan pembungaan.

Petakan digenangi air setinggi $10 \mathrm{~cm}$ pada umur 10 hst hingga 90 hst, dengan tujuan untuk mengendalikan tumbuhnya gulma dan mempermudah itik dalam mencari makanan berupa hama. Sepuluh hari menjelang panen hingga saat panen lahan atau petakan 
dikeringkan dengan tujuan mempercepat dan meratakan proses pematangan buah padi dan memudahkan saat pemanenan. Panen dilakukan pada saat tanaman berumur 110 - 115 hari dengan ciri daun bendera tanaman padi telah menguning. Pengamatan meliputi tinggi tanaman, jumlah anakan, jumlah anakan produktif, bobot bulir per malai, bobot 1000 bulir, dan produksi per petak. Data dianalisis varian (Gomez \& Gomez, 1995) dan jika berbeda nyata dilakukan uji lanjut dengan uji BNJ pada taraf $5 \%$.

\section{HASIL DAN PEMBAHASAN}

Hasil analisis ragam integrasi populasi itik dalam meningkatkan produktivitas tanaman padi sawah terhadap peubah yang diamati ditampilkan pada Tabel 1.

Berdasarkan hasil analisis ragam terhadap semua peubah yang diamati menunjukkan bahwa populasi itik terintegrasi tanaman padi berpengaruh nyata terhadap bobot bulir permalai, berpengaruh sangat nyata terhadap bobot 1000 bulir dan produksi per petak namun tidak berpengaruh nyata terhadap tinggi tanaman, jumlah anakan, dan jumlah anakan produktif. $1 \mathrm{Uji}$ BNJ dan data tabulasi perlakuan populasi itik (P) terhadap semua peubah yang diamati dapat dilihat pada Tabel 2 .

Hasil analisis ragam menunjukkan bahwa populasi itik berpengaruh tidak nyata terhadap tinggi tanaman, namun dapat dilihat dari trendnya populasi itik 2 ekor (P2) menghasilkan tinggi tanaman 129,40 cm dan tanpa populasi itik (P0) yaitu 123,65 cm. Tabel 2 dan Gambar 1 menunjukkan tinggi tanaman dari masing-masing populasi tersebut.

Demikian juga pada hasil analisis ragam populasi itik berpengaruh tidak nyata terhadap jumlah anakan padi. Berdasarkan Tabel 2 dan Gambar 2, jumlah anakan dari masing-masing populasi itik tersebut

Tabel 1. Hasil analis is ragam integras i populasi itik dalam meningkatkan produktivitas tanaman padi sawah

\begin{tabular}{|c|c|c|c|}
\hline No & Peubah yang diamati & F hitung perlakuan & $\mathrm{KK}(\%)$ \\
\hline 1 & Tinggi tanaman $(\mathrm{cm})$ & $1,43 \mathrm{tn}$ & $2,70 \%$ \\
\hline 2 & Jumlah anakan ( batang ) & $0,94 \mathrm{tn}$ & $10,62 \%$ \\
\hline 3 & Jumlah anakan produktif ( batang ) & $1,75 \mathrm{tn}$ & $8,94 \%$ \\
\hline 4 & Bobot bulir per malai (g) & $3,15 *$ & $8,98 \%$ \\
\hline 5 & Bobot 1000 bulir ( g ) & $6,56 * *$ & $1,29 \%$ \\
\hline 6 & Produksi per petak ( kg ) & $4,88 * *$ & $6,18 \%$ \\
\hline
\end{tabular}

Tabel 2. Pengaruh populasi itik (P) terhadap semua peubah yang diamati.

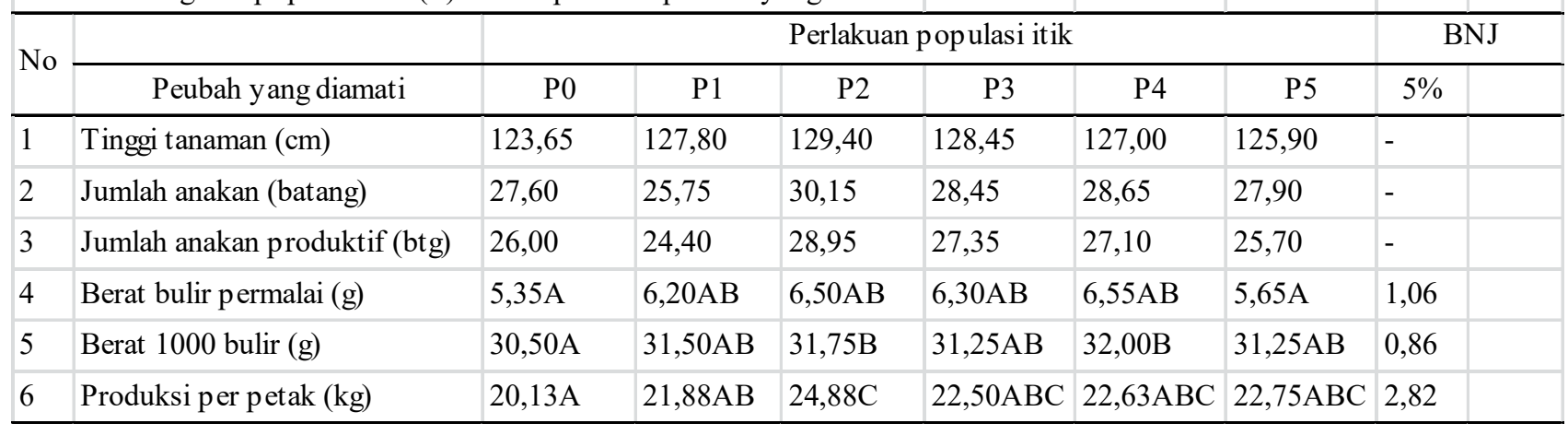




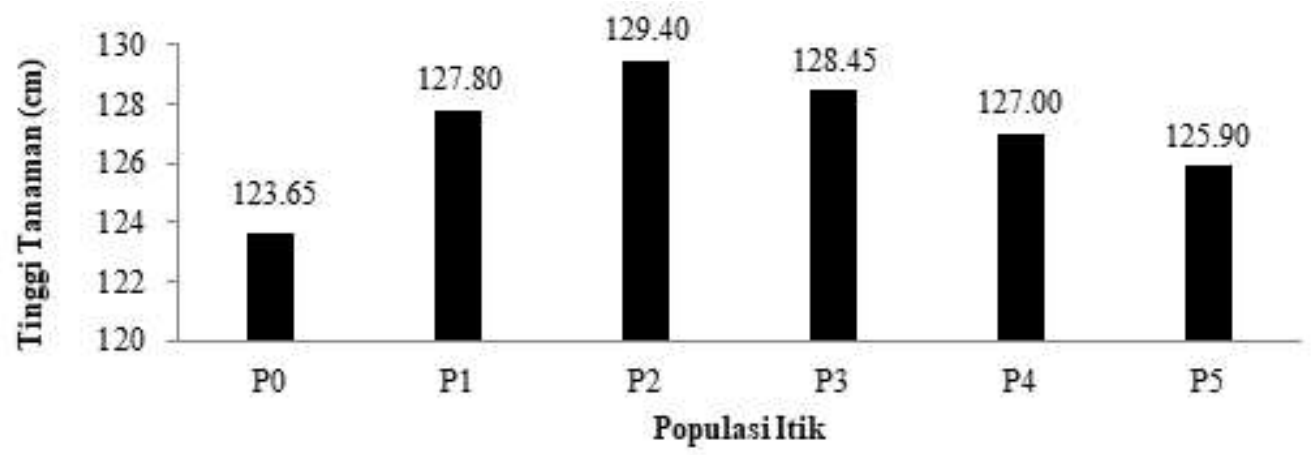

Gambar 1. Tinggi tanaman padi pada setiap terintegrasi populasi itik.

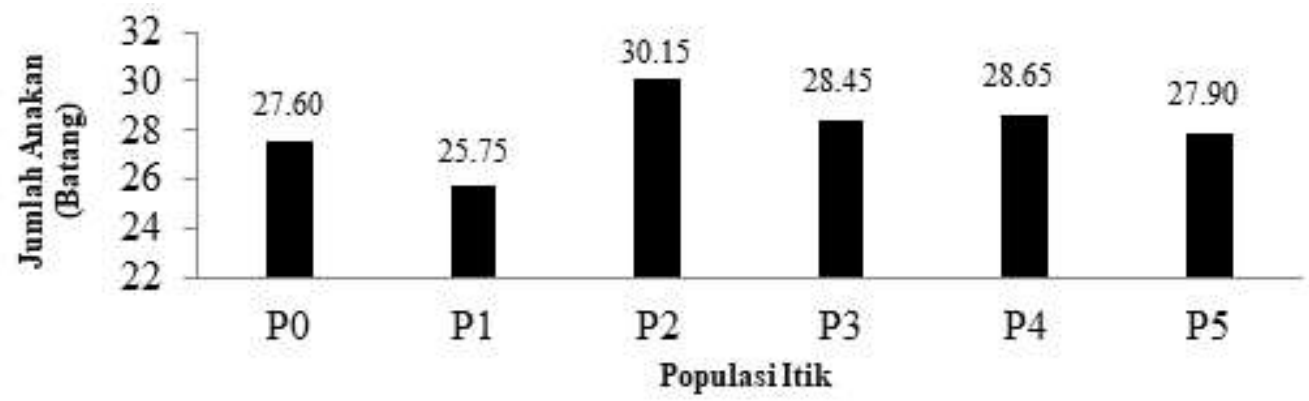

Gambar 2. Jumlah anakan padi pada setiap perlakuan populasi itik.

memberi trend populasi itik 2 ekor (P2) menghasilkan jumlah anakan 30,15 batang dan populasi itik 1 ekor (P1) yaitu 25,75 batang.

Hasil analisis ragam menunjukkan bahwa perlakuan populasi itik berpengaruh tidak nyata terhadap jumlah anakan produktif. Berdasarkan Tabel 2 dan Gambar 3 jumlah anakan produktif mempunyai trend pada P2 (2 ekor itik) memberikan 28,95 batang anakan produktif dan P1 (1 ekor itik) yaitu 24,40 batang anakan produktif.
Hasil uji BNJ pada taraf 5\% menunjukan bahwa perlakuan P0 berbeda nyata dengan perlakuan P2 dan P4 tetapi tidak berbeda nyata dengan perlakuan P1, P3, dan P5. Bobot bulir per malai dari masingmasing populasi 2 ekor itik dan 4 ekor itik memberikan bobot 6,50- 6,55 gram dan yang terendah adalah populasi tanpa itik (P0) yaitu 5,35 gram. Bobot bulir per malai pada setiap perlakuan populasi itik dapat dilihat pada Gambar 4.

batang anakan produktif.

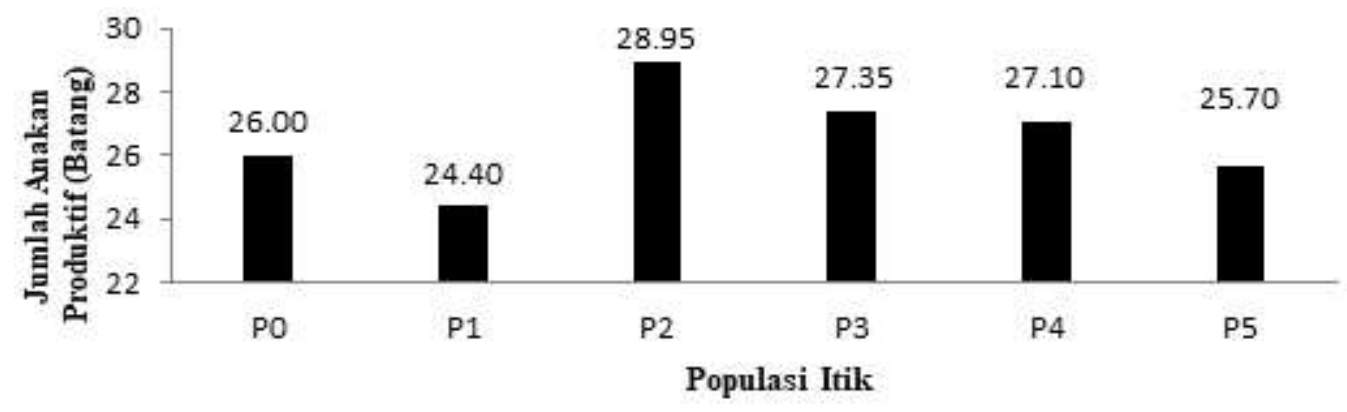

Gambar 3. Jumlah anakan produktif padi pada setiap perlakuan populasi itik. 


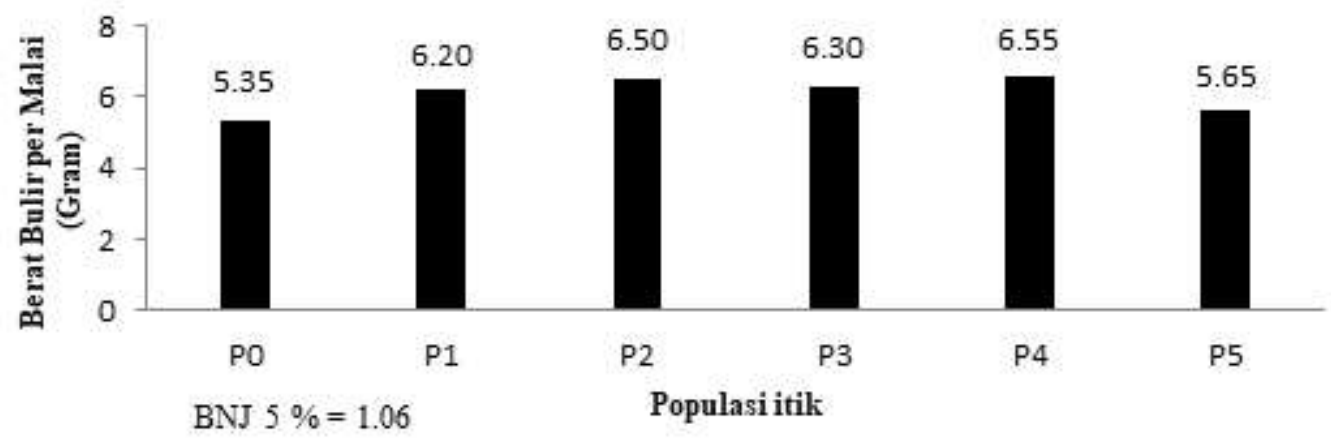

Gambar 4. Bobot bulir per malai padi pada setiap perlakuan populasi itik.

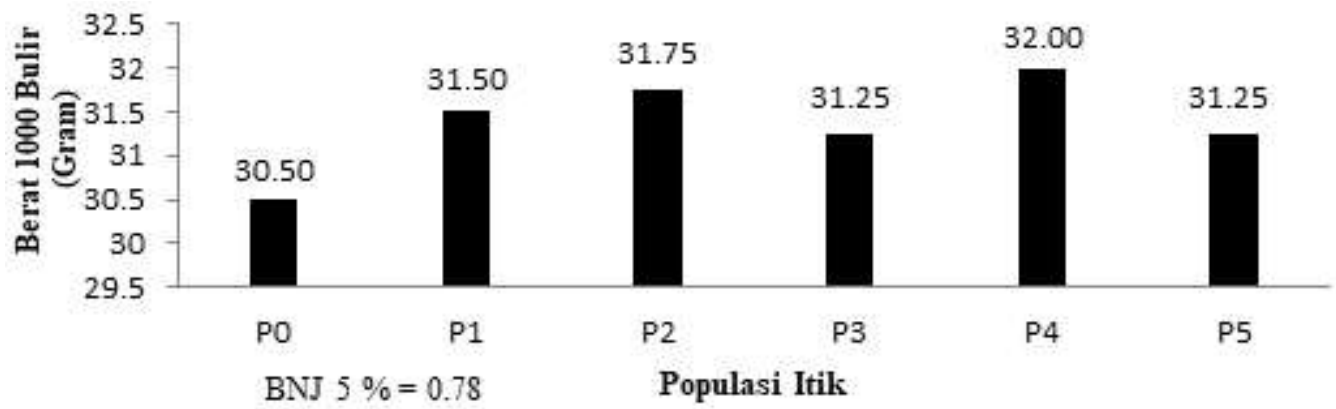

Gambar 5. Bobot 1000 bulir padi pada setiap perlakuan populasi itik.

Hasil uji BNJ pada taraf 5\% menunjukan berbeda sangat nyata dengan perlakuan P2, berbeda bahwa P0 berbeda nyata dengan perlakuan P1, P2 nyata dengan perlakuan, P3, P4 dan P5 namun tidak dan P4 namun tidak berbeda dengan perlakuan, P3, berbeda nyata dengan P1. Produksi per petak dari dan P5. Populasi itik 4 ekor(P4) menghasilkan bobot adanya itik 2 ekor (P2) menghasilkan 24,88 kg atau terberat yaitu 32,00 gram dan yang teringan terdapat setara dengan 7,090 ton/ha GKG dan produksi pada tanpa populasi itik (P0) yaitu 30,50 gram terendah terdapat pada populasi tanpa itik ( $\mathrm{P} 0)$ yaitu (Gambar 5).

Hasil uji BNJ pada taraf 5\% menunjukan (Gambar 6).

bahwa produksi per petak karena perlakuan P0

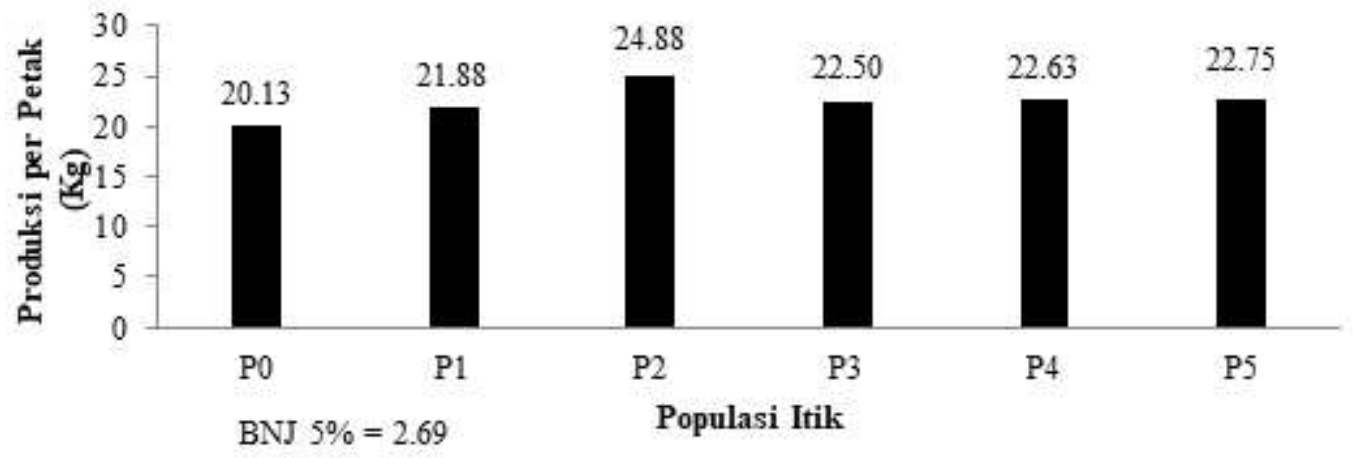

Gambar 6. Produksi per petak padi pada setiap perlakuan populasi itik. 
Populasi itik berpengaruh pada peubah bobot 1000 bulir, bobot per petak dan bobot bulir per malai. Menurut Holidi et al. (2015), itik berperan dalam memperbaiki sifat fisik tanah karena adanya aktivitas itik di sawah, itik juga ikut menambah unsur bahan organik ke dalam tanah dari kotorannya, selain itu itik juga berperan dalam pengendalian gulma dan hama penyakit karena gulma dan hama menjadi makanan itik.

Populasi itik tidak berpengaruh terhadap tinggi tanaman, jumlah anakan dan jumlah anakan produktif. Hal ini diduga itik sama peranannya yaitu andil pada pemberian kecukupan unsur hara yang dibutuhkan tanaman dalam fase vegetatif(Holidi et al, 2015).

Itik dengan populasi 2 ekor per petak (P2) menunjukan hasil terbaik terhadap peubah yang di amati. Hal ini sejalan dengan penelitian Beigi et al, (2013) yang menyatakan bahwa populasi itik 4001200 ekor per petak merupakan populasi itik terbaik di lahan sawah. Itik dengan populasi 2 ekor per petak (P2 memudahkan itik untuk bergerak di antara rumpunan tanaman padi dalam melakukan aktifitas mencari makanan, sehingga ketersediaan makanan yang ada di lahan sawah untuk populasi itik 2 ekor per petak tersedia maksimal. Selain itu populasi 2 ekor per petak (600 ekor/ha) tidak menggangu pertumbuhan tanaman padi.

Pada perlakuan tanpa itik (P0) menunjukan hasil terendah pada peubah yang diamati. Hal ini disebabkan tidak adanya itik diduga mengakibatkan pertumbuhan dan peroduksi tanaman kurang maksimal.
Produksi tanaman menurun jika unsur hara yang dibutuhkan tidak terpenuhi secara maksimal. Menurut Lingga \& Marsono (2005), kotoran itik mengandung unsur hara yang mampu mempengaruhi pertumbuhan dan produksi dari suatu tanaman. Tanpa itik namun juga tanpa penyiangan maka tumbuh banyak gulma di pertanaman padi yang sekaligus menjadi sarang hama disekitar tanaman padi. Sistem pertanian padi terintegrasi itik merupakan pertanian yang mampu menjaga keseimbangan ekosistem sehingga aliran nutrisi (unsur hara) dan energi terjadi secara seimbang. Keseimbangan inilah yang akan menghasilkan produktivitas yang tinggi dan berkelanjutan produksi yang terjaga secara efektif dan efisien.

\section{KESIMPULAN}

Hasil penelitian menunjukkan bahwa populasi itik berpengaruh nyata terhadap bobot bulir per malai , berpengaruh sangat nyata terhadap bobot 1000 bulir dan produksi per petak namun tidak berpengaruh nyata terhadap tinggi tanaman, jumlah anakan, dan jumlah anakan produktif. Populasi 2 ekor itik per petak (P2) atau setara dengan 600 ekor per hektar menghasilkan pertumbuhan dan produksi tertinggi.

\section{DAFTAR PUSTAKA}

Beigi M,G., P. Hemmatollah, Arastoo \&A. Ghasem. 2013. Combined effect of duck and Azolla on dry matter partitioning of rice (Oryza sativa L.) in the integrated rice-duck farming. International Journal of Farming and Allied Sciences and Natural Resources, University, Sari, Iran 
Gomez \& Gomez. 1995. Prosedur Statistik untuk Penelitian Pertanian. Edisi Kedua. Universitas Indonesia (UI Press).

Handaka, A. Hendriadi, \& T. Alamsyah. 2009. Perspektif pengembangan mekanisasi pertanian dalam sistem integrasi ternak-tanaman berbasis sawit, padi dan kakao. Prosiding Workshop Nasional Dinamika dan Keragaan Sistem Integrasi Ternak-Tanaman. Pusat Penelitian dan Pengembangan Peternakan. Bogor.

Holidi. Safriyani,E. \& L.Y. Affandi. 2015. The Growth and Yield of Five High-Yield Rice Varieties Following Integrated Farming Rice-Duck Treatments " Promoting Local Resaurces For Food and health "University OfBengkulu.

Kementerian Pertanian, 2015. Balai Besar Penelitian \& Pengembangan Sumberdaya Lahan Pertanian. Badan Penelitian dan Pengembangan Pertanian. Balai Penelitian Tanah. Kementrian Pertanian. Jakarta.

Lingga, P \& Marsono. 2005. Petunjuk Penggunaan Pupuk. Penebar Swadaya. Jakarta.

Mansyur., N.P- Indrani., I. Susilawati \& T. Dhalika. 2009. 3. Sistem Usaha tani Tanaman-Ternak pada Lahan Kering Dataran Rendatr di Kabupaten Takalar, Sulawesi Selatan. Balai Pengkajian Teknologi Pertanian (BPTP) Sulawesi Selatan. 